\title{
International child abduction and the best interests of the child: an analysis of judicial reasoning in two jurisdictions
}

\section{Charlotte Mol \& Thalia Kruger}

To cite this article: Charlotte Mol \& Thalia Kruger (2018) International child abduction and the best interests of the child: an analysis of judicial reasoning in two jurisdictions, Journal of Private International Law, 14:3, 421-454, DOI: 10.1080/17441048.2018.1525074

To link to this article: https://doi.org/10.1080/17441048.2018.1525074

Published online: 29 Oct 2018.

Submit your article to this journal $₫$

Џ Article views: 111

View Crossmark data $\complement$ 


\title{
International child abduction and the best interests of the child: an analysis of judicial reasoning in two jurisdictions
}

\author{
Charlotte $\mathrm{Mol}^{*}$ and Thalia Kruger**
}

The Hague Child Abduction Convention aims to secure the speedy return of abducted children. Judges can use a limited number of grounds for refusal. They may not make an in-depth assessment of the merits of any custody issue. The Convention on the Rights of the Child provides that the best interests of the child shall be a primary consideration in all actions concerning children. This article analyses the use that judges make in their decisions on the concept of "the best interests of the child". For this purpose it scrutinizes the case law on international child abduction of the Netherlands and England and Wales. By using software designed for qualitative research, the authors are able to make an objective and systematic analysis. This article confirms the hypothesis that the concept of the best interests of the child is often used without substance, and sometimes only to endorse conclusions that would have possibly been reached in any event.

Keywords: international child abduction; wrongful removal; wrongful retention; best interests of the child; the Netherlands; England and Wales; Hague Child Abduction Convention; Brussels IIa (Regulation 2201/2003); return orders; second chance procedure

\section{A. Introduction}

International child abduction is a form of transgression of the law that is particularly harmful to those involved, most of all the child. A child is abruptly taken from his or her known environment and placed in a new, often uncertain situation. To deal with this matter, the Hague Conference on Private International Law in 1980 concluded a convention containing a specific return mechanism. ${ }^{1}$ The purpose of the return mechanism is that the child should be speedily brought back to his or her habitual residence. The substance of the dispute, including a

*Charlotte Mol, PhD Candidate, Utrecht Centre for European Research into Family Law, Faculty of Law, Economics and Governance, Utrecht University, Utrecht, Netherlands.

${ }^{* *}$ Thalia Kruger, Senior Lecturer, Faculty of Law, University of Antwerp, Antwerp, Belgium; Honorary Research Associate, University of Cape Town, South Africa. Email: thalia.kruger@uantwerpen.be.

${ }^{1}$ Hague Convention of 25 October 1980 on the Civil Law Aspects of the International Abduction of Children. 
full assessment of the best long-term solution for the child, must then be resolved by the courts of the child's habitual residence.

According to the UN Children's Rights Convention, the best interests of the child must be a primary consideration in all actions that concern that child. ${ }^{2}$ This principle is widely revered. Both the Hague Child Abduction Convention and the Brussels IIa Regulation, the two main legal instruments on child abduction in the EU, explicitly refer to the best interests of the child. ${ }^{3}$ The European Court of Human Rights (ECtHR) has emphasized the importance of the best interests of each individual child in child abduction cases. However, bringing it into practice is often difficult. Judges must decide real cases where real children are caught up in battles between their parents or in other tough conditions. Moreover, the nature and context of parental child removal is not static. In particular, joint custody and other legal restrictions on the removal of children have expanded in many jurisdictions, and the profile of the taking and left behind parent has dramatically changed since the Convention's adoption in 1980 .

This article investigates the application of the concept of the best interests of the child in return proceedings, aimed at a quick return. The purpose of this article is not to rehash the criticism of the ECtHR's case law in the field of international child abduction. Rather the contribution that the authors seek to make is to show in an objective and methodically rigorous manner how domestic judges integrate the concept of the best interests of the child explicitly in their case law. These judges are in the unenviable position that they are simultaneously bound by the time constraints of the Hague Child Abduction Convention and Brussels $\mathrm{Ia}^{4}$ and by the requirements to assess the best interests of the child, albeit not in depth. ${ }^{5}$ This article describes how they perform this task. It seeks to determine whether courts use factors to give content to the best interests of the child, use a set formula, do an in-depth analysis, or accept that the Hague Child Abduction Convention sufficiently takes the best interests of the child into account in its grounds for refusal so that a separate assessment is unnecessary.

After describing our methodology we will set out the ECtHR's case law on this matter. We will then turn to two legal systems in which we have thoroughly analysed return cases and the place that the "best interests of the child" takes in the motivation of the decisions, namely The Netherlands and England and Wales.

\footnotetext{
${ }^{2}$ United Nations Convention on the Rights of the Child 1989, Art 3 and Charter of Fundamental Rights of the European Union [2012] OJ C326/391, Art 24(2).

${ }^{3}$ The preamble of the Hague Child Abduction Convention states that signatory States are "firmly convinced that the interests of children are of paramount importance in matters relating to their custody". The Brussels IIa Regulation refers in Recitals 12 and 13, and in various provisions throughout the text, to the best interests of the child.

${ }^{4}$ Both instruments mention a six-week timeframe: Hague Child Abduction Convention Art 11; Brussels IIa Art 11(3). The latter purporting to have a more mandatory character.

${ }^{5}$ The extent to which they have to consider the child's best interests is further elaborated below.
} 
The case law of the Court of Justice of the EU on international child abduction does not form part of this study, as that court does not explicitly discuss the best interests of the child. ${ }^{6}$ This Court only assists the national court in finding the correct interpretation of EU law; it does not apply the law to the facts. This explains why it is not the Court's role to grapple with the concept of the best interests of the individual child involved.

\section{B. Methodology}

The researchers opted for an in-depth case law analysis to discover how courts in the Netherlands and England and Wales determine and make use of the best interests of the child in international child abduction cases. We used the contents analysis method, ${ }^{7}$ supported by the data analysis software program NVivo to code and organize the cases. This method, although not often used in legal research, has allowed the researchers to make a systematic and unbiased analysis of a large number of cases.

\section{Search and selection methods}

The researchers searched and selected cases from online legal databases. For the Netherlands this was Rechtspraak.nl and for England and Wales it was Westlaw $U K$ and BAILII. As great amounts of case law are available in both jurisdictions, the search was limited to cases from 1 January 2005 onwards. The searches took place in the beginning of February 2016, and thus include results until 10 February

\footnotetext{
${ }^{6}$ The Court does refer to the concept briefly as part of the legislation, for purposes of jurisdiction and the concept of proximity (Case C-403/09 PPU Detiček v Sgueglia EU: C:2009:810 at 38; Case C-296/10 Purrucker v Vallés Pérez EU:C:2010:665 at 84; Case C-376/14 PPU $C v M$ EU:C:2014:2268 at 50), choice of forum (Case C-656/13 L v M EU:C:2014:2364 at 39 and 48-49), hearing the child (Case C-491/10 PPU Aguirre Zarraga $v$ Pelz EU:C:2010:828 at 63-64 and 66-68), recognition and enforcement (Case C-211/10 PPU Povse v Alpago [2010] ECLI:EU:C:2010:400 at 80-83; Case C-455/15 PPU $P \vee Q$ EU:C:2015:763 at 38-39 and 53) and transfer of a case (Case C-428/15 Child and Family Agency $v$ JD EU:C:2016:458 at 58-60. However, this Court does not discuss factors to give content to the "best interests of the child". One possible exception is Case C-400/10 PPU McB $v$ LE EU:C:2010:582 where the Court refers at 62 to "circumstances surrounding the birth of the child, the nature of the parents' relationship, the relationship of the child with each parent, and the capacity of each parent to take the responsibility of caring for the child" as facts apt to protect the child's best interests. A second possible exception is Case C-428/15 Child and Family Agency $v$ JD where at para 59 the Court gives guidance on a relatively narrow formulation of the best interests test in a transfer case: "To that end, the court having jurisdiction must assess any negative effects that such a transfer might have on the familial, social and emotional attachments of the child concerned in the case or on that child's material situation".

${ }^{7}$ See MA Hall and RF Wright, "Systematic Content Analysis of Judicial Opinions" (2008) 96 California Law Review 63.
} 
2016. The reason for choosing 1 January 2005 as starting date is twofold: this allowed us to have a time-range of 10 years and the Brussels IIa Regulation ${ }^{8}$ became fully applicable on 1 March $2005 .^{9}$ Although the Regulation was not applicable in all the cases analysed, ${ }^{10}$ considering it alongside the Hague Child Abduction Convention cases provided us with a more complete picture of child abduction cases.

To ensure that the analysis was not influenced by a pre-selection of cases, broad search terms were used. For the Netherlands this was internationale kinderontvoering, which led to 288 search results, and for England and Wales we used "international child abduction", which led to 533 search results in Westlaw UK and 212 search results in BAILII (including many overlaps). A primary selection led to the removal of all the non-relevant cases. Cases could be non-relevant for various reasons. Firstly, only cases which concerned a return procedure whether in Hague Convention proceedings, non-Hague Convention proceedings or the overriding return mechanism of Brussels $\mathrm{IIa}^{11}$ - are relevant for the analysis. "Return procedure" was taken in a broad sense also with regards to the type of proceedings: it includes enforcement proceedings and interlocutory decisions. Secondly, the Scottish and Northern-Irish cases had to be removed from the Westlaw UK and BAILII selection. Finally, many decisions appeared more than once as exact copies in the search results or as copies in the two English databases, so these were also filtered out. In total, 218 cases from the Netherlands and 179 from England and Wales remained.

\section{Limitations of the research}

One limitation encountered in the research is that not all decisions are published in the Netherlands and in England and Wales. In the Netherlands, the Besluit selectiecriteria uitsprakenregister Rechtspraak.nl 2012 states that all decisions concerning return orders on the ground of the Hague Child Abduction Convention must be published, ${ }^{12}$ but prior to 2012 not all decisions were published. ${ }^{13}$ In England and Wales, although all Supreme Court judgments are reported, not all other cases are. Editors of law report series decide whether or not to report a

\footnotetext{
${ }^{8}$ Regulation 2201/2003 of 27 November 2003 concerning jurisdiction and the recognition and enforcement of judgments in matrimonial matters and the matters of parental responsibility, [2003] OJ L338/1.

${ }^{9}$ Art 72 Brussels IIa.

${ }^{10}$ The Regulation only applies to child abduction cases from one EU Member State to another and some of the cases were already initiated before the date of application of the Regulation.

${ }^{11}$ Art 11(6)-(8) Brussels IIa.

${ }^{12} \operatorname{Art~4(1)(f).~}$

${ }^{13} \mathrm{See}$ www.rechtspraak.n1/Uitspraken-en-nieuws/Uitspraken/Paginas/Selectiecriteria.aspx accessed on 22 October 2017.
} 
case. The difference in publication guidelines might explain why more cases were found from the Netherlands than from the larger jurisdiction, England and Wales. Although it is not clear what the effects are on our study, we limited our research to published cases and did not contact courts or lawyers to obtain more data. Doing so would not have been exhaustive but rather random and therefore not methodologically sound.

A second limitation concerns the selection of cases. Several judges, while not referring explicitly to the best interests of the child, might consider these interests implicitly. In order to keep this article within reasonable limits, to avoid speculation and not lose objectivity, we have not included these cases in the analysis.

Third, we could unfortunately not research the reasons why judges often ${ }^{14}$ refrain from referring to the best interests of the child. Obtaining such information would require a different research methodology, such as interviews. The researchers consciously decided not take interviews with judges: the aim was not to show how judges think, but the elements that their decisions contain.

\section{NVivo}

NVivo is a qualitative data analysis software programme which supports researchers in conducting qualitative data analysis. NVivo was used in this case law analysis for various reasons. ${ }^{15}$ It allowed the systematic organization of the 397 decisions. It was used as a tool for coding different variables to limit the risk of personal bias and was used to perform queries to create overviews of the data.

All 397 decisions were imported into NVivo. We then "classified" the cases separately according to the following variables: abducting parent (mother/ father); state abducted from; state abducted to; decision outcome (non-return and exceptions to return, return order, no wrongful abduction, etc.); and court's use of child's best interest (explicit, implicit, considered not relevant). Subsequently, the cases were read and coded in NVivo one at a time. For the coding we highlighted relevant sentences as "nodes", which represent the different codes. While some codes were determined in advance (eg explicit mention of child's best interest, exception invoked/granted/not-granted, etc.), many codes were created throughout the process. In total we used 66 codes. Here a limitation must be noted: due to the lack of prior experience with coding, we did not start with a sample group of cases to test the codes. Instead when new codes were created, the cases which had already been coded had to be re-read and further coded. The end result was a thoroughly coded dataset.

The output of the case law coding in NVivo was twofold. On the one hand, per code we obtained a list of nodes with all the relevant sections of the decisions. This

\footnotetext{
${ }^{14}$ See numbers in the table.

${ }^{15}$ This analysis was done by Charlotte Mol.
} 
allowed for a specific analysis of the cases per code, for example all the explicit mentions of the child's best interests. Additionally, the matrix coding query function of NVivo was employed. While this function is mainly aimed at quantitative conclusions, it also allowed for the creation of large tables that show the co-occurrences of codes and variables per case. This overview was useful to see which factors combined lead to certain results.

The analysis below focuses on the courts' explicit use of the concept of the best interests of the child in return proceedings. Therefore, our discussion only includes a limited number of cases from the overall coded sample (see the below table).

\begin{tabular}{lllll}
\hline & \multicolumn{2}{l}{ Use of child's best interests (number of cases) } & \\
\cline { 2 - 4 } Jurisdiction & Explicit use $^{\mathrm{a}}$ & Implicit use $^{\mathrm{b}}$ & No use & Total \\
\hline England and Wales & 36 & 82 & 61 & 179 \\
The Netherlands & 40 & 98 & 80 & 218 \\
Total & 76 & 180 & 141 & 397 \\
\hline
\end{tabular}

aExplicit use: when 'child's best interests' or 'best interests of the child' is referred to.

'Implicit use: when a child's situation is discussed by the court without reference to the child's interests.

'No use: when no discussion of child's interests or situation occurs in the judgment.

\section{Legal frameworks}

International child abduction is governed by international, EU and national legislation In this section we will only briefly present the legal framework relevant for the cases that we have analysed. ${ }^{16}$ As the case law analysis includes cases between the Netherlands and England and Wales and between either of those two countries and other EU jurisdictions, the EU legislation must be discussed.

\section{International legal framework}

The Hague Child Abduction Convention takes as its point of departure that it is not in children's interests to be abducted and that such action must be discouraged. Discouraging such action means showing parents that abducted children will be

\footnotetext{
${ }^{16}$ See PR Beaumont and PE McEleavy, The Hague Convention on International Child Abduction (Oxford University Press, 1999); R Schuz, The Hague Child Abduction Convention: A Critical Analysis (Hart, 2013); K Trimmings, Child Abduction within the European Union (Hart, 2013); the special issue of the Journal of Family Law and Practice 1 (2010); studies by the Swiss Institute of Comparative Law; and M Jonker et al, Internationale kinderontvoering: De uitvoeringspraktijk van inkomende zaken in Nederland, Engeland \& Wales, Zweden en Zwitserland (Boom Juridische Uitgevers, 2015), also available with English summary at https://www.wodc.nl/onderzoeksdatabase/2383-uitvoeringspraktijkinternationale-kinderontvoering.aspx accessed on 10 January 2018.
} 
returned expeditiously. The Convention therefore introduces a mechanism to return the child expeditiously. ${ }^{17}$

To get the balance right, the Convention also allows a limited number of grounds for refusing such return. These are that the parent (or institution) requesting the return did not actually exercise custody rights, ${ }^{18}$ that there is a grave risk that the return would expose the child to psychological or physical harm or place the child in an intolerable situation; ${ }^{19}$ that the child objects to the return and has an age and degree of maturity that makes it appropriate to take into account his or her views; ${ }^{20}$ and that the return would not be permitted by fundamental principles of the requested State. ${ }^{21}$ The court requested to return the child may only consider these grounds; it may not decide on the merits of rights of custody. ${ }^{22}$ If none of the limited grounds for refusal presents itself, the Court must order the return of the child.

This means that the Convention does not allow the court to make a comprehensive assessment of the best interests of the child including determining any custody issue. First, that would be against the idea of a principled return unless extreme circumstances justify a refusal of return. The Convention is set up to be one of venue, merely rectifying the unnatural and illegal situation by the return so that the correct court can hear the custody dispute. ${ }^{23}$ Second, a full-blown assessment of the best interests of the child would possibly entail the involvement of experts, as well as the taking of evidence, and would thus prolong the return proceedings beyond the allowed six-week period. ${ }^{24}$

In 2006, an attempt to write the consideration of the best interests of the child as a ground for refusal into the Convention failed. At the Special Commission of the Hague Conference on Private International Law monitoring the functioning of the 1980 Child Abduction Convention in 2006 the Swiss delegation proposed such an amendment. It was, however, not accepted. The Commission instead clarified that the best interests of the child lay at the heart of both this Convention and the UN

\footnotetext{
${ }^{17}$ Art 11-12 Hague Child Abduction Convention.

${ }^{18}$ Art 13(1)a) Hague Child Abduction Convention.

${ }^{19}$ Art 13(1)b) Hague Child Abduction Convention.

${ }^{20}$ Art 13(2) Hague Child Abduction Convention.

${ }^{21}$ Art 20 Hague Child Abduction Convention.

${ }^{22}$ Art 16 Hague Child Abduction Convention.

${ }^{23}$ This principle is echoed by the Hague Convention of 19 October 1996 on Jurisdiction, Applicable Law, Recognition, Enforcement and Co-operation in Respect of Parental Responsibility and Measures for the Protection of Children (Hague Child Protection Convention). According to this Convention, the Court of the habitual residence of the child has jurisdiction to decide matters of parental responsibility (Art 5). Contra: Schuz (supra n 16) at $\mathrm{p} 443$.

${ }^{24}$ Art 11 Hague Child Abduction Convention provides that the court must act expeditiously. If it has not reached a decision in six weeks, the applicant or central authority of the requesting state can ask it to provide reasons for the delay. Art 11(3) Brussels IIa Regulation reinforces the obligation to decide within six weeks.
} 
Convention on the rights of the Child. ${ }^{25}$ It further noted that the words "there is a grave risk that his or her return would ... place the child in an intolerable situation" address the situation "where the return of the child would not necessarily create a grave risk, but where it would still be inappropriate to order the return". ${ }^{26}$ Thus, it seems that while the grave-risk exception is to be interpreted narrowly, the reference to an intolerable situation does give some scope for judges to consider the child's situation a bit more broadly than a strict evaluation of risk.

While there are other international and bilateral conventions, they were not the subject of the case law we analysed and are therefore not further discussed. ${ }^{27}$

\section{European Union legal framework}

All of the European Union States are among the States party to the Hague Child Abduction Convention. Nevertheless, the European Union took the controversial step in 2003 to introduce the issue of international child abduction into Brussels IIa (sometimes also referred to as Brussels IIbis) ${ }^{28}$ While Brussels IIa takes precedence over the Hague Convention, ${ }^{29}$ it has not replaced the Convention. Therefore, both instruments operate alongside each other when a child is abducted from one EU Member State to another Member State. It should be noted here that the research was conducted prior to the Brexit decision. The analysed case law dates

\footnotetext{
${ }^{25}$ See the Report on the Fifth Meeting of the Special Commission to Review the Operation of the Hague Convention of 25 October 1980 on the Civil Aspects of International Child Abduction and the Practical Implementation of the Hague Convention of 19 October 1996 on Jurisdiction, Applicable Law, Recognition, Enforcement and Co-operation in Respect of Parental Responsibility and Measures for the Protection of Children (30 Oct. - 9 Nov. 2006) https://assets.hcch.net/upload/wop/abd_2006_rpt-e.pdf accessed on 22 October 2017, paras 162-67. See also A Bucher, "The New Swiss Federal Act on International Child Abduction" (2008) 4 Journal of Private International Law 139; A Bucher, "The Convention Should Be Revised!" (2006) 11 The Judges' Newsletter 41 https://assets.hcch.net/upload/news2006.pdf accessed on 22 October 2017; S Fischer, "How far did the Conclusions and Recommendations of the Fifth Meeting of the Special Commission Advance the Interpretation of Article 13(1)b, Grave Risk Defence?" (2007) 12 The Judges' Newsletter 54 https://assets.hcch.net/upload/news2007.pdf accessed on 22 October 2017; W Duncan, "Keeping the 1980 Hague Child Abduction Convention up to Speed: Is It Time for a Protocol?" (2010) 1 Journal of Family Law and Practice 4.

${ }^{26}$ Report of the Special Commission (see n 25 above) para 166.

${ }^{27}$ Apart from the Hague Child Abduction Convention, the Council of Europe has enacted the European Convention on Recognition and Enforcement of Decisions concerning Custody of Children and on Restoration of Custody of Children (Luxembourg, 1980); full text available on the website of the Council of Europe https://www.coe.int/en/web/ conventions/full-list/-/conventions/treaty/105 accessed on 22 October 2017. This Convention is in force in the Netherlands and the United Kingdom.

${ }^{28}$ Recital 17 and Art 11 Brussels IIa; PE McEleavy, "The New Child Abduction Regime in the European Union: Symbiotic Relationship or Forced Partnership?" (2005) 1 Journal of Private International Law 5; Trimmings (supra $\mathrm{n} 16$ ).

${ }^{29}$ Art 60e) Brussels IIa.
} 
from a time when Brussels IIa was in full operation in England and Wales. While the impact of Brexit on the family law instruments is still under debate, ${ }^{30}$ the UK will remain bound by the Hague Child Abduction Convention. The analysis of how judges interpret the best interests of the child will therefore stay relevant.

Brussels IIa has attempted to enhance the return of abducted children and to restrict the grounds for refusal under the Hague Convention. The ground for refusal concerning the grave risk for a child to psychological or physical harm may not be used if adequate measures of protection have been made in the Member State to which the child is to be returned. ${ }^{31}$ The Regulation enhances the duty of courts to give the child the opportunity to be heard. ${ }^{32}$

Most controversially, the Regulation has introduced the so-called second chance procedure, or overriding mechanism. This entails that if a court in the Member State to which the child has been abducted refuses the return, the courts of the Member State of the former habitual residence gets an opportunity to overturn this decision. ${ }^{33}$ This court may then order the return of the child.

These EU-made additions to the Hague Abduction Convention apply in the Netherlands and in the United Kingdom (pre-Brexit) when children are abducted to or from other EU Member States, with the exception of Denmark. ${ }^{34}$ When children are abducted to or from Contracting States of the Hague Convention outside the EU, this Convention applies without the EU additions. Both scenarios are found in the analysed case law.

Brussels IIa is currently the subject of a Recast. ${ }^{35}$ Some of the proposed amendments aim to better protect the best interests of the child. The Commission's

\footnotetext{
${ }^{30}$ See for instance the Child and Family Law Quarterly's special issue on Brexit: issue 3 of 2017; PR Beaumont, "Private International Law Concerning Children in the UK after Brexit: Comparing Hague Treaty Law with EU Regulations", Centre of Private International Law of the University of Aberdeen, Working Paper No. 2017/2, available at https://www.abdn.ac.uk/law/documents/CPIL\%20Working\%20Paper\%20No\%202017 2. pdf accessed on 9 January 2018; Susie Alegre, Didier Bigo, Elspeth Guild, Elif Mendos Kuskonmaz, Hager Ben Jaffel and Julien Jeandesboz, "The Implications of the United Kingdom's Withdrawal from the European Union for the Area of Freedom, Security and Justice", study for the LIBE Committee, European Parliament, available at http://www. europarl.europa.eu/RegData/etudes/STUD/2017/596824/IPOL_STU(2017)596824_EN. pdf accessed on 9 January 2018, esp p 39 and following.

${ }^{31}$ Art 11(4) Brussels IIa.

${ }^{32}$ Art 11(2) Brussels IIa.

${ }^{33}$ Art 11(6)-(8) Brussels IIa; criticized by P R Beaumont, L Walker and J Holliday, "Conflicts of EU Courts on Child Abduction: The Reality of Article 11(6)-(8) Brussels IIa Proceedings Across the EU" (2016) 12 Journal of Private International Law 211; defended by L Carpaneto, "In-depth Consideration of Family Life v. Immediate Return of the Child in Child Abduction Proceedings Within the EU" (2014) Rivista di diritto internazionale private e processuale 936 .

${ }^{34}$ Brussels IIa does not apply in Denmark: see Recital 31.

${ }^{35}$ The Commission's Proposal for a Recast was published on 30 June 2016 as $\operatorname{COM}(2016)$ 411 final. The European Parliament's report of 17 January 2018 is available at http://www. europarl.europa.eu/sides/getDoc.do?type=TA\&reference=P8-TA-2018-0017\&language $=$ EN\&ring=A8-2017-0388 on accessed 9 February 2018.
} 
Proposal for amendment includes a clarification that the "best interests of the child" must be interpreted in the light of Article 24 of the Charter of Fundamental Rights of the EU and of the UN Children's Rights Convention. ${ }^{36}$

\section{National legal frameworks in the Netherlands and in England and Wales}

Both legal systems have incorporated the international and EU law instruments. ${ }^{37}$ We will not discuss these implementations in detail, but only insofar as they are relevant for the case law analysis. ${ }^{38}$

The Dutch legislation refers to the Hague Abduction Convention, but does not rewrite its provisions. ${ }^{39}$ The purpose of the Dutch legislation is to regulate procedural details. It does not specifically mention the best interests of the child, but some of its provisions aim at better proceedings, in line with good practices identified by the Hague Conference on Private International Law. Return proceedings are concentrated at the court of The Hague. ${ }^{40}$ These proceedings must receive priority treatment. ${ }^{41}$ The child must be given the opportunity to be heard. ${ }^{42}$ The proceedings are held behind closed doors. ${ }^{43}$ In order to speed up the entire process, the term for any appeal is only two weeks. ${ }^{44}$

The Dutch legislation was subjected to an important amendment in 2012. This amendment changed the role of the Central Authority, which no longer has the task to institute the return proceedings; the task is now fulfilled by lawyers. ${ }^{45}$ In the same legislative amendment, the role of the Dutch Supreme Court (Hoge Raad)

\footnotetext{
${ }^{36}$ See the proposed amendment to Recital 13.

${ }^{37}$ In the Netherlands: Uitvoeringswet Internationale Kinderontvoering (1990). This legislation was first enacted at the time of the entry into force of the Hague Child Abduction Convention in the Netherlands and has subsequently been amended several times. In England and Wales: Child Abduction and Custody Act (UK, 1985) and Family Procedure Rules (England and Wales, 2010), Part 12, Chapter 6. For a detailed analysis of the Dutch legislation and its application see GCAM Ruitenberg, De toepassing van het Haags Kinderontvoeringsverdrag in Nederland en het belang van het kind (Boom Juridische uitgevers 2015) and Jonker et al (supra n 16) at 29-76.

${ }^{38}$ For brief information on the implementing legislation in all Member States see Swiss Institute of Comparative Law, "Cross-border parental child abduction in the European Union: Study for the LIBE Committee” (2015) www.europarl.europa.eu/RegData/etudes/ STUD/2015/510012/IPOL STU(2015)510012 EN.pdf accessed on 22 October 2017.

${ }^{39}$ This is not necessary according to the constitutional law of the Netherlands.

${ }^{40}$ Art 11(1) Uitvoeringswet Internationale Kinderontvoering.

${ }^{41}$ Art 13(2) Uitvoeringswet Internationale Kinderontvoering.

${ }^{42}$ Art 13(2) Uitvoeringswet Internationale Kinderontvoering.

${ }^{43}$ Art 13(2) Uitvoeringswet Internationale Kinderontvoering.

${ }^{44}$ Art 13(7) Uitvoeringswet Internationale Kinderontvoering.

${ }^{45}$ For more information, see Ministry of Justice (The Netherlands), "Handreiking Stelsel Internationale Kinderontvoering: Centrale autoriteit Internationale Kinderontvoering" (2012) www.kinderontvoering.org/sites/default/files/media/nl/docs/downloads/verdragen/ Handreiking-kinderontvoering-NL.pdf accessed on 22 October 2017; and Jonker et al (supra n 16).
} 
was amended. From 2012 onwards, the right to appeal to the Supreme Court was limited to cassation in the interest of the law. ${ }^{46}$

Perhaps the most peculiar feature of Dutch law on international child abduction is that the return proceedings are available not only with respect to States Party to the Hague Convention, but to all cases. ${ }^{47}$ This means that no matter where the child has been abducted from, the left-behind parent can institute return proceedings in the Netherlands. This will become apparent in our case law analysis below, where we discuss cases involving Egypt and Sudan even though these States have not ratified the Hague Child Abduction Convention.

The Hague Abduction Convention is incorporated into UK law ${ }^{48}$ and the procedural details are worked out in the Family Procedure Rules for England and Wales. These Rules do not refer to the best interests of the child in general, but contain such reference in various specific rules on procedural steps. Return proceedings must be brought before the High Court. ${ }^{49}$ The Rules insert short time lines for the various steps in the procedure. ${ }^{50}$ It is possible that the child be made a party to the proceedings. If not, the court can give directions about the way in which the child's wishes and feelings are to be ascertained or the appointment of a litigation friend for a child. ${ }^{51}$ The general term for appeal applies, which is three weeks to file the application for leave to appeal. However, the court may direct a different time limit. ${ }^{52}$ The Central Authority does not have the task of being a party to the proceedings.

In England and Wales, like in most other States, the specific procedure for return is only available when a child has been abducted from another Contracting State. ${ }^{53}$ In cases where a child has been abducted to England or Wales from a non-Hague State, a parent can request the return under the inherent jurisdiction of the High Court. $^{54}$

\section{European Court of Human Rights case law}

The Hague Child Abduction Convention considers it not in the interests of children to be abducted and this is why it introduced a speedy return

\footnotetext{
${ }^{46}$ As a result, the option of an appeal with the Dutch Supreme Court is no longer open to the parties, but only to the Prosecutor General and any judgment of the Supreme Court is without effect on the case concerned. See Art 13(8) Uitvoeringswet Internationale Kinderontvoering.

${ }^{47}$ Art 1c) Uitvoeringswet Internationale Kinderontvoering.

${ }^{48}$ Child Abduction and Custody Act 1985, Schedule 1.

${ }^{49}$ S4(a) Child Abduction and Custody Act; Rule 12.45 Family Procedure Rules.

${ }^{50}$ For instance Rule $12.49,12.50$ and 12.51 Family Procedure Rules.

${ }^{51}$ Rule $12.48(1)$ e), f) and i) Family Procedure Rules.

${ }^{52}$ Rule 30.4 Family Procedure Rules.

${ }^{53}$ Rule 12.44 Family Procedure Rules; Section 2 Child Abduction and Custody Act.

${ }^{54}$ Such an application will either be dealt with in a summary hearing with a prompt return or will require a more detailed enquiry. See further, 12F PD 3.1 and In Re J (A Child) (FC) [2005] UKHL 40.
} 
mechanism. ${ }^{55}$ Thus the Convention takes a particular approach to the best interests of the child, looking at children collectively. ${ }^{56}$ It aims at reducing child abduction, which would have a positive effect for children in general.

The UN Convention on the Rights of the Child (CRC) provides that the best interests of the child shall be a primary consideration in all actions concerning children. ${ }^{57}$ This Convention is focused on the rights of each individual child. ${ }^{58}$ This Convention's approach has caused a clash with the collective approach of the Child Abduction Convention. Since the abducting parent is nowadays often the primary caretaker, ${ }^{59}$ and since this parent often refuses to return, there is, nowadays more than in the past, a tension between the return and the best interests of the child.

The European Court of Human Rights has issued a number of judgments on the application in the Council of Europe States of the Hague Child Abduction Convention. ${ }^{60}$ In these judgments the Court considers the best interests of the children involved and builds a legal framework for national courts. The case law is most often based on Article 8 of the ECHR, namely the right to respect for private and family life, ${ }^{61}$ and sometimes on Article 6, the right to a fair

\footnotetext{
${ }^{55}$ J Paton, "The Correct Approach to the Examination of the Best Interests of the Child in Abduction Convention Proceedings Following the decision of the Supreme Court in Re E (Children) (Abduction: Custody Appeal)" (2012) 8 Journal of Private International Law 547.

${ }^{56}$ Ibid, 549.

${ }^{57}$ Art 3 CRC. See also UN Committee on the Rights of the Child, "General Comment No. 14 (2013) on the right of the child to have his or her best interests taken as a primary consideration (art. 3, para. 1)" (29 May 2013) UN Doc CRC/C/GC/14.

${ }_{58}$ Including the right not to be illicitly transferred: Art $11 \mathrm{CRC}$.

${ }^{59}$ N Lowe, "A Statistical Analysis of Applications Made in 2003 under the Hague Convention of 25 October 1980 on the Civil Aspects of International Child Abduction, Part 1 Overall Report" (Preliminary Doc n 3) (2008) 22 http://www.hcch.net/upload/wop/abd pd03e1_2007.pdf accessed on 22 October 2017; T Kruger, International Child Abduction: The Inadequacies of the Law (Hart, 2011), 84-85.

${ }^{60}$ Reviewed and discussed by PR Beaumont, K Trimmings, L Walker and J Holliday, "Child Abduction: Recent Jurisprudence of the European Court of Human Rights" (2015) 64 International and Comparative Law Quarterly 39; PE McEleavy, "The European Court of Human Rights and the Hague Child Abduction Convention: Prioritising Return or Reflection?" (2015) 62 Netherlands International Law Review 365.

${ }^{61}$ Proceedings brought by left-behind parents: Ignoccolo-Zenide v Romania, App no 31679/ 96, 25 January 2000; Tiemann v France, App no 47457/99, 27 April 2000; Iglesias Gil and A.U.I. v Spain, App no 56673/00, 29 April 2003; Maire v Portugal, App no 48206/99, 26 June 2003; Monory v Hungary and Romania, App no 71099/01, 15 April 2005; Bianchi v Switzerland, App no 7548/04, 22 June 2006; Bajrami v Albania, App no 35853/04, 12 December 2006; Carlson v Switzerland, App no 49492/06, 6 November 2008; Raban v Romania, App no 25437/08, 26 October 2010; Shaw v Hungary, App no 6457/09, 26 July 2011; Karrer v Romania, App no 16965/10, 21 February 2012; Ilker Ensar Uyanik $v$ Turkey, App no 60328/09, 3 May 2012; Raw and Others v France, App no 10131/11, 7 March 2013; López Guió v Slovakia, App no 10280/12, 3 June 2014; Blaga v Romania, App no 54443/10, 1 July 2014; Hromadka and Hromadka v Russia, App no
} 
trial. ${ }^{62}$ Left-behind as well as abducting parents have turned to the ECtHR, sometimes even in the same case. ${ }^{63}$

Although the Hague Child Abduction Convention is older than the CRC, it is possible to interpret the Child Abduction Convention in light of children's rights. The Neulinger and Shuruk case ${ }^{64}$ caused concern in this regard. This was not the first time that the Court ruled that there was a violation of Article 8 of the ECHR, but it was the first time that the Court found a violation of this provision in favour of the abducting parent. In earlier cases, the Court found the applications by abducting parents inadmissible. ${ }^{65}$ In Maumousseau ${ }^{66}$ the Court held that there was no violation of Article 8, although the Court did in this case analyse the interpretation and application of the "best interests of the child". The Court identified two considerations for the analysis:

22909/10, 11 December 2014; R.S. v Poland, App no 6377/09, 21 July 2015; M.A. v Austria, App no 4097/13, 15 January 2015; Adžić v Croatia, App no 22643/14, 12 March 2015; Ferrari v Romania, App no 1714/10, 28 April 2015; G.S. v Georgia, App no 2361/13, 21 July 2015; Frisancho Perea v Slovakia, App no 383/13, 21 July 2015; R.S. v Poland, App no 63777/09, 21 October 2015; Henrioud v France, App no 21444/ 11, 5 November 2015; K.J. v Poland, App no 30813/14, 1 March 2016; G.N. v Poland, App no 2171/14, 19 July 2016; Severe v Austria, App no 53661/15, 21 September 2017; Vilenchik v Ukraine, App no 21267/14, 3 October 2017. Proceedings brought by abducting parents: Tiemann v Germany, App no 47458/99, 27 April 2000; Eskinazi and Chelouche v Turkey, App no 14600/05, 6 December 2005; Paradis and Others v Germany, App no 4065/ 04, 4 September 2007; Maumousseau and Washington v France, App no 39388/05, 7 December 2007; Neulinger and Shuruk v Switzerland, App no 41618/07 (Grand Chamber) 6 July 2010; Sneersone and Kampanella v Italy, App no 14737/09, 12 July 2011; M.R. and L.R. v Estonia, App no 13420/12, 4 June 2012; B. v Belgium, App no 4320/11, 10 July 2012; X. v Latvia, App no 27853/09 (Grand Chamber) 26 November 2013; Rouiller v Switzerland, App no 3592/08, 22 July 2014; Gajtani v Switzerland, App no 43730/07, 9 September 2014; Phostira Efthymiou and Ribeiro Fernandes $v$ Portugal, App no 66775/11, 5 February 2015. See also the Fact Sheet on International Child Abductions (October 2016) www.echr.coe.int/Documents/FS_Child_abductions_ENG.pdf accessed on 22 October 2017.

${ }^{62}$ See for instance Monory v Hungary and Romania, App no 71099/01, 15 April 2005; Gajtani v Switzerland, App no 43730/07, 9 September 2014; Hoholm v Slovakia, App no 35632/13, 13 January 2015; Henrioud v France, App no 21444/11, 5 November 2015. See also PR Beaumont, "The Jurisprudence of the European Court of Human Rights and the European Court of Justice on the Hague Convention on International Child Abduction" in Collected Courses of the Hague Academy of International Law (Vol 335 Martinus Nijhoff, 2009) 9.

${ }^{63}$ Povse v Austria, App no 3890/11, 18 June 2013 and M.A. v Austria, App no 4097/13, 15 January 2015.

${ }^{64}$ Neulinger and Shuruk $v$ Switzerland, App no 41618/07 (Grand Chamber) 6 July 2010.

${ }^{65}$ Tiemann v Germany, App no 47458/99, 27 April 2000; Eskinazi and Chelouche v Turkey, App no 14600/05, 6 December 2005; Paradis and Others v Germany, App no 4065/04, 4 September 2007.

${ }^{66}$ Maumousseau and Washington v France, App no 39388/05, 7 December 2007. 
firstly, to guarantee that the child develops in a sound environment and that a parent cannot take measures that would harm its health and development; secondly, to maintain its ties with its family, except in cases where the family has proved particularly unfit, since severing those ties means cutting a child off from its roots. ${ }^{67}$

\section{The Court was satisfied that the domestic (French) court had}

conducted an in-depth examination of the entire family situation and of a whole series of factors, in particular of a factual, emotional, psychological, material and medical nature, and made a balanced and reasonable assessment of the respective interests of each person, with a constant concern for determining, as requested of them, what the best solution would be for [the child] in the context of a request for her return to $\ldots$ her country of birth. ${ }^{68}$

Reading Neulinger it seemed that the Child Abduction Convention's and the Human Rights obligations were juxtaposed. The Grand Chamber of the ECtHR ruled that the principle of the child's best interests consists of two limbs: the maintenance of the child's ties with his or her family in so far as possible and the development of the child in a sound environment, without harm to his or her health and development. ${ }^{69}$ This is similar to what the Court had stated in Maumousseau. The order of the two limbs is strangely inverted, but this is probably without significance as the limbs seem to be placed adjacent to each other, rather than in an order of priority.

According to the Grand Chamber, the best interests of the child must be assessed in each individual case instead of ordering the return "automatically or mechanically". ${ }^{70}$ National courts must make an

in-depth examination of the entire family situation and of a whole series of factors, in particular of a factual, emotional, psychological, material and medical nature, and ma $[\mathrm{k}] \mathrm{e}$ a balanced and reasonable assessment of the respective interests of each person, with a constant concern for determining what the best solution would be for the abducted child in the context of an application for his return to his country of origin. $^{71}$

Ironically, these words are similar to those that the Court had employed in Maumousseau (see above), but the outcome was different here as the Court found a violation in favour of the abducting parent.

\footnotetext{
${ }^{67} \mathrm{Ibid}$, para 67.

${ }^{68} \mathrm{Ibid}$, para 74.

${ }^{69}$ Neulinger and Shuruk $v$ Switzerland, App no 41618/07 (Grand Chamber) 6 July 2010, para 136.

${ }^{71} \mathrm{Ibid}$, para 138 .

${ }^{71} \mathrm{Ibid}$, para 139.
} 
The finding was followed in subsequent cases, ${ }^{72}$ also for intra-EU abductions ${ }^{73}$ and for the overriding return procedure. ${ }^{74}$ Also in this phase the court assessing the return of the children must make a proper assessment of their best interests.

The Grand Chamber judgment in Neulinger marked the start of a severe debate. The judgment was widely criticized. ${ }^{75}$ Some thought that the judgments rang the death toll of the efficient Hague Child Abduction Convention, which is a forum convention and by its nature does not give the last word to the court assessing the return. The ECtHR took issue with the Convention's approach of looking at the interests of children in general. The Court considers that the best interests of each individual child should be paramount. A particular child cannot pay the price for all children.

In considering the Neulinger judgment, circumstances of the ECtHR and of the facts of the judgment must be taken into account. First, this was at a time when the Court faced a high caseload which caused a great delay in the delivery of justice. While the case was pending at the ECtHR, the enforcement of the Swiss judgment was suspended. It took almost three years for this case to make its way through the system of the ECtHR. This Court has since then cleaned up its house, tightened its rules and reduced its backlog. ${ }^{76}$ However, the Court's proceedings unfortunately still take too long, especially if one considers the six-week time-frame and the need for expeditious procedures.

The facts of the Neulinger case did not amount to an everyday situation, but attested to harsh living conditions. The father had become fundamentalist in his religion. This put strain on the life of the family. Hard cases unfortunately can make bad law.

The Grand Chamber revisited the matter of the coexistence of the Hague Convention and human rights obligations in $X v$ Latvia.$^{77}$ Here the Grand Chamber explicitly stated that "a harmonious interpretation of the European

\footnotetext{
${ }^{72}$ Illker Ensar Uyanik $v$ Turkey, App no 60328/09, 3 May 2012 (brought by the left-behind parent); B. v Belgium, App no 4320/11, 10 July 2012 (brought by the abducting parent).

${ }^{73}$ Karrer v Romania, App no 16965/10, 21 February 2012.

${ }^{74}$ Śneersone and Kampanella v Italy, App no 14737/09, 12 July 2011.

${ }^{75}$ LJ Silberman, "The Hague Convention on Child Abduction and Unilateral Relocations by Custodial Parents: A Perspective from the United States and Europe - Abbott, Neulinger, Zarraga" (2011) 63 Oklahoma Law Review 733, 743-44; L Walker and PR Beaumont, "Shifting the Balance Achieved by the Abduction Convention: The Contrasting Approaches of the European Court of Human Rights and the European Court of Justice" (2011) 7 Journal of Private International Law 231, 232; Schuz (supra n 16) 309; Beaumont et al (supra $\mathrm{n}$ 61). This issue was also discussed by the Special Commission on the practical operation of the 1980 and 1996 Hague Conventions (1-10 June 2011), see the Conclusions and Recommendations https://assets.hcch.net/upload/wop/concl28sc6_e.pdf paras 47-49, accessed on 17 August 2018.

${ }^{76}$ The Court rules were amended various times, especially Rule 47 . This rule makes it unnecessary for the Court to examine incomplete cases, which allows it to focus on complete and correct files.

${ }^{77}$ X v Latvia, App no 27853/09 (Grand Chamber) 26 November 2013.
} 
Convention and the Hague Convention" is possible. ${ }^{78}$ It set two conditions for such harmonious interpretation: 1) the national court must genuinely take into account the factors that could constitute an exception for return, particularly when one of the parties to the proceedings raises them, and give a judgment that is sufficiently reasoned on this point; and 2) the national court must assess these factors in the light of Article 8 ECHR. This case was followed in subsequent cases, ${ }^{79}$ also when the return was refused but the ECtHR was of the opinion that the assessment of the best interests of the child was not sufficient. ${ }^{80}$

Thus the Grand Chamber gave an important nuance to its earlier judgment, extending a friendly word to the Hague Convention without lowering the required protection of human rights. In our view the judgment finds a satisfactory balance, emphasizing the importance of the interests of every child. However, the practical implementation is not always easy. Abducting parents can go to great lengths to submit reports of varying sources and credibility to courts. Assessing them properly takes time, and time is limited. Especially, taking into consideration that the ECtHR has emphasized that wasting time can amount to a violation of the right to family life. ${ }^{81}$

\section{E. The Netherlands}

The analysis of Dutch case law encompasses 40 cases, including two cases by the Hoge Raad (Dutch Supreme Court). ${ }^{82}$ In both cases the Supreme Court was faced with appeals alleging violations of Article 8 ECHR, which were rejected in both cases. ${ }^{83}$ According to the Supreme Court Article 8 ECHR must be explained in light of the Hague Convention, therefore the national authorities ought to follow the Hague Convention provisions. The case law analysis shows that these decisions reflect the overall view of the Dutch courts that the best interests of the child, as also protected through Article 8 ECHR and Article 3 CRC, are sufficiently protected by the Hague Convention provisions and procedure. In the next paragraphs first the non-return orders will be discussed followed by the decisions in which return was ordered.

\footnotetext{
${ }^{78} \mathrm{Ibid}$, para 106.

${ }^{79}$ Ferrari v Romania, App no 1714/10, 28 April 2015; G.S. v Georgia, App no 2361/13, 21 July 2015; Frisancho Perea v Slovakia, App no 383/13, 21 July 2015; R.S. v Poland, App no 63777/09, 21 October 2015; K.J. v Poland, App no 30813/14, 1 March 2016; G.N. v Poland, App no 2171/14, 19 July 2016.

${ }^{80}$ G.S. v Georgia, App no 2361/13, 21 July 2015.

${ }^{81}$ Adžić v Croatia, App no 22643/14, 12 March 2015.

${ }^{82}$ The Hoge Raad does not reassess facts, but only considers questions of law since the legislative amendment in 2012 as described above. This explains why both cases are from 2007 and why more recent cases from the Supreme Court are lacking.

${ }^{83}$ Dutch Supreme Court 28 September 2007, NL:HR:2007:BB3192; Dutch Supreme Court 28 September 2007, NL:HR:2007:BB3193.
} 


\section{Non-return orders}

In 35 out of 218 Dutch decisions return was refused on the grounds of the exceptions in Article 12, 13 or 20 of the Hague Convention. In four of these cases the Dutch courts explicitly mentioned the best interests of the child.

Two of these decisions concerned the same case of three children abducted by their mother from Egypt to the Netherlands. ${ }^{84}$ The court of first instance refused the return of the eldest child, who was almost 16 years at the time, because she objected to returning to Egypt where she felt unsafe due to the position of women in Egypt and the political unrest. ${ }^{85}$ It then had to consider the return of the younger two children. The court considered that the mother would not return with the children if return were ordered, partially because her position as a divorced woman of non-Egyptian origin would be extremely difficult. The court then emphasized that an order for return would have the result of separating the two youngest children from both their mother and their elder sister. The court of first instance considered this to be contrary to the best interests of these specific children due to their young age (twins of 1 year old), but also due to what the court states to be a rationale of the Hague Convention: respecting and protecting family life. ${ }^{86}$ The court of appeal upheld the decision of the first instance court. It based its refusal of return on Article 13(1)(b) of the Hague Child Abduction Convention (risk for the child). ${ }^{87}$ It linked this ground to the children's best interests by emphasizing the difficulty of return for the mother, the fact that the eldest sister would stay in the Netherlands and the possibility that the father would not be in Egypt either. These elements created the real risk that the children would be left in Egypt all by themselves. In these two decisions, the courts closely link the children's best interests to the aim of protecting family life and ensuring that the children are not separated from their core family members at a very young age.

In the case of a child whose father had taken her to the Netherlands via the United Kingdom from Sudan two-and-a-half years prior to the decision, the first instance court refused the return on the ground of Article 13(1)(b). ${ }^{88}$ According to the court, ordering the return would run contrary to the best interests of the child, especially due to her young age (4 years old). The reason why return would be problematic was threefold. Firstly, the child no longer had an emotional connection with her mother and also would not be able to communicate with her mother, because she did not speak Arabic. Secondly, the court recognized that the Sudanese culture is very different from the western culture to which the child had

\footnotetext{
${ }^{84}$ Court of Appeal The Hague 24 July 2013, NL:GHDHA:2013:3225; District Court of The Hague 7 June 2013, NL:RBDHA:2013:CA2639.

${ }^{85}$ District Court of The Hague 7 June 2013, NL:RBDHA:2013:CA2639, applying Art 13(2) Hague Child Abduction Convention on the objection by the child.

${ }^{86}$ District Court of The Hague 7 June 2013, NL:RBDHA:2013:CA2639.

${ }^{87}$ Court of Appeal The Hague 24 July 2013, NL:GHDHA:2013:3225.

${ }^{88}$ District Court of The Hague 11 April 2014, NL:RBDHA:2014:4526.
} 
grown accustomed. The court noted especially that the child had left at a very young age and therefore would return to a - for her - unknown environment. Lastly and most importantly, a return would separate the child from her father and half-sister with whom she had a close connection. International contact would be impossible due to the lack of financial means as well as telephone and internet possibilities in Sudan. The court finds the Hague Convention's scope to include the respect and protection of family life, even if the child's family life with her father was caused by the father breaching the mother's custody rights. Again the court relates the child's best interests to the protection of family life.

In the final case, the child had been residing in the Netherlands for more than one year since the abduction from Bulgaria. This lead to the refusal of the return based on the fact that the child was settled in the new environment. ${ }^{89}$ The court of appeal found the child to have been settled in the Netherlands on the basis of various factors. Firstly, the child's new social environment played a significant role. In the Netherlands the child was attending a local nursery, playing with local children and had contact with almost all family members. She had been too young prior to the abduction to have any social contacts. Secondly, the court determined that the child spoke Dutch well. Another core factor was the absence of the left-behind parent, the father, in the child's life. The father had since the abduction, barely been in contact with the child because of his work in a foreign third country and had barely taken any measures to visit or contact the child. This factor was taken in combination with the fact that the mother, the abducting parent, had always been and remained the primary caretaker of the child. In light of these considerations and the decision not to order the return of the child, the court finds it to be in the child's best interests to have a good contact arrangement so that the relationship with the father can continue. It therefore suggests that the parents try mediation. As this case concerned a situation to which Article 12(2) applies, with the child having been in the Netherlands for more than a year, it is understandable that the child's best interests play a different role in the court's reasoning than in the previous cases.

In all four decisions where the return was refused, the courts link the best interests of the child to the protection of family life. The potential separation of the family members and lack of contact with them are found to be contrary to the child's best interests. ${ }^{90}$ This is in line with the considerations that the ECtHR set out in Maumousseau ${ }^{91}$ and Neulinger. ${ }^{92}$ as corrected by $X v$ Latvia. $^{93}$ In these cases the

\footnotetext{
$\overline{{ }^{89} \text { Court of Appeal The Hague } 27 \text { January 2016, NL:GHDHA:2016:131, applying Art 12(2) }}$ Hague Child Abduction Convention.

${ }^{90}$ For further comments, see Ruitenberg (supra n 38).

${ }^{91}$ Maumousseau and Washington v France, App no 39388/05, 7 December 2007, para 67.

${ }^{92}$ Neulinger and Shuruk $v$ Switzerland, App no 41618/07 (Grand Chamber) 6 July 2010, para 136.

${ }^{93}$ X. v Latvia, App no 27853/09 (Grand Chamber) 26 November 2013.
} 
Dutch courts manage to fit the assessment of the best interests of the child into the framework of the Hague Convention's grounds for refusal. It also (implicitly) acknowledges that the assessment of the best interests is not a full-blown examination. This is particularly clear in the last-mentioned case, where the court acknowledges the importance of the child to have contact with both parents, but does not attempt to rule on this matter beyond recommending mediation.

\section{Return orders}

In 95 out of 218 decisions the Dutch courts ordered the return of the child(ren). In 34 of these decisions the best interests of the child were explicitly mentioned.

Most of these decisions (25 out of 34) date from 2012 or later. ${ }^{94}$ In these cases a clear trend of the courts to raise the child's best interests ex officio at the end of the decisions is visible. In 15 decisions, the court starts this ex officio consideration by stating that it has otherwise also not been shown that by ordering the return the interests of the child, which are also paramount in cases of international child abduction, are infringed. ${ }^{95}$ It is interesting to note that the overwhelming majority of these decisions (13 of the 15) emanate from courts of appeal. In three other decisions, the court starts by emphasizing that Article 8 ECHR must be seen in conjunction with the Hague Child Abduction Convention, because the best interests of the child are paramount. ${ }^{96}$ In most decisions (15 out of 18 ) the court then continues by explaining what the concept of the child's best interests seeks to ensure. This includes on the one hand the reunification of the child with his or her parents as soon as possible so that the abducting parent does not gain an unfair advantage by the lapse of time, and on the other hand that the child grows up in a safe

\footnotetext{
${ }^{94}$ Due to the changed publication policy in the Netherlands (discussed above) we cannot deduct that return applications have been more successful following the 2012 amendments in the Dutch Implementation Act.

${ }^{95}$ Court of Appeal The Hague 13 February 2013, ECLI:NL:GHDHA:2013:667; Court of Appeal The Hague 7 May 2014, NL:GHDHA:2014:1589; Court of Appeal The Hague 26 May 2014, NL:GHDHA:2014:1796; Court of Appeal The Hague 4 June 2014, NL: GHDHA:2014:1976; Court of Appeal The Hague 15 October 2014, NL: GHDHA:2014:3722; Court of Appeal The Hague 25 February 2015, NL: GHDHA:2015:467; Court of Appeal The Hague 20 January 2016, NL:GHDHA:2016:67; Court of Appeal The Hague 18 January 2012, NL:GHSGR:2012:BV5608; Court of Appeal The Hague 27 June 2012, NL:GHSGR:2012:BW9796; Court of Appeal The Hague 22 August 2012, NL:GHSGR:2012:BX5499; Court of Appeal The Hague 10 October 2012, NL:GHSGR:2012:BY0156; Court of Appeal The Hague 14 March 2012, NL:GHSGR:2012:BY0419; Court of Appeal The Hague 12 December 2012, NL: GHSGR:2012:BZ3746; District Court of The Hague 27 August 2014, NL: RBDHA:2014:10658; District Court of The Hague 1 November 2012, NL:RBSGR:2012: BY3832.

${ }^{96}$ District Court of The Hague 3 January 2013, NL:RBDHA:2013:BY8769; District Court of The Hague 27 August 2014, NL:RBDHA:2014:10658; District Court of The Hague 20 January 2015, NL:RBDHA:2015:767.
} 
environment. ${ }^{97}$ This explanation did not appear out of thin air; it is a clear replication of the ECtHR's two-limb test in Neulinger ${ }^{98}$ and Maumousseau. ${ }^{99}$

Following this explanation, the courts often very briefly discuss how these two aspects (maintenance of ties with family and development in a safe environment) of the child's best interests are sufficiently protected upon return. The reunification of the child with both parents is considered sufficiently covered when the abducting parent can return with the child(ren) ${ }^{100}$ and/or when the left-behind parent can take care of the children upon return. ${ }^{101}$

In three cases where the abducting parent would not return with the child(ren) the first aspect was still safeguarded, because the contact between the children and the abducting parent would continue. ${ }^{102}$ In all three cases, the abducting parent could return - even if they would rather not due to career perspectives or lack of housing. In one other case, the return was considered justified because the children were sufficiently mature and no longer dependent on the abducting parent so that they could return without their mother. ${ }^{103}$

The other aspect, namely that the child grows up in a safe environment, has received less attention in the analysed cases. In one case, which concerned a child with multiple disabilities, the court found this second aspect to be safeguarded by the fact that there are sufficient care facilities offered by the relevant authorities for the child upon return. ${ }^{104}$ This is in line with the Recommendations

\footnotetext{
${ }^{97}$ Court of Appeal The Hague 13 February 2013, NL:GHDHA:2013:667; Court of Appeal The Hague 7 May 2014, NL:GHDHA:2014:1589; Court of Appeal The Hague 4 June 2014, NL:GHDHA:2014:1976; Court of Appeal The Hague 15 October 2014, NL: GHDHA:2014:3722; Court of Appeal The Hague 25 February 2015, NL: GHDHA:2015:467; Court of Appeal The Hague 20 January 2016, NL:GHDHA:2016:67; Court of Appeal The Hague 18 January 2012, NL:GHSGR:2012:BV5608; Court of Appeal The Hague 27 June 2012, NL:GHSGR:2012:BW9796; Court of Appeal The Hague 22 August 2012, NL:GHSGR:2012:BX5499; Court of Appeal The Hague 10 October 2012, NL:GHSGR:2012:BY0156; Court of Appeal The Hague 14 March 2012, NL:GHSGR:2012:BY0419; Court of Appeal The Hague 12 December 2012, NL: GHSGR:2012:BZ3746; District Court of The Hague 27 August 2014, NL: RBDHA:2014:10658.

${ }^{98}$ Neulinger and Shuruk $v$ Switzerland, App no 41618/07 (Grand Chamber) 6 July 2010, para 136.

${ }^{99}$ Maumousseau and Washington v France, App no 39388/05, 7 December 2007, para 67.

${ }^{100}$ Court of Appeal The Hague 13 February 2013, NL:GHDHA:2013:667; Court of Appeal The Hague 12 December 2012, NL:GHSGR:2012:BZ3746.

${ }^{101}$ Court of Appeal The Hague 7 May 2014, NL:GHDHA:2014:1589; Court of Appeal The Hague 25 February 2015, NL:GHDHA:2015:467; Court of Appeal The Hague 20 January 2016, NL:GHDHA:2016:67; Court of Appeal The Hague 12 December 2012, NL: GHSGR:2012:BZ3746.

${ }^{102}$ Court of Appeal The Hague 10 October 2012, NL:GHSGR:2012:BY0156; Court of Appeal The Hague 4 June 2014, NL:GHDHA:2014:1976; District Court of The Hague 27 August 2014, NL:RBDHA:2014:10658.

${ }^{103}$ Court of Appeal The Hague 18 January 2012, NL:GHSGR:2012:BV5608.

${ }^{104}$ Court of Appeal The Hague 7 May 2014, NL:GHDHA:2014:1589.
} 
by the Special Commissions of the Hague Conference on Private International Law that safe return should be enhanced, rather than stretching the scope of Article 13(1)(b) of the Hague Child Abduction Convention. ${ }^{105}$ This principle was also taken up in the Brussels IIa Regulation. ${ }^{106}$

When looking at all the decisions in which the return was ordered and in which the best interests of the child are explicitly discussed, in addition to the approach set out above, four common views on the best interests of the child can be distinguished.

The first common view, held explicitly by three decisions from courts of first instance, is that as a starting point a return order, leading to the quick recovery of the situation prior to the abduction, is in the best interests of the child and can therefore only be rejected in particular circumstances. ${ }^{107}$ This view is in line with the point of departure of the Hague Convention to return children expeditiously. It also complies with the approach that the Dutch courts took in the cases where they refused return (discussed above).

The second common view concerns the case law of the European Court of Human Rights on Article 8 ECHR, more specifically, the Neulinger judgment. ${ }^{108}$ The European Court of Human Rights' two-limb understanding of the principle of the child's best interests in international child abduction cases as determined in Neulinger has influenced the Dutch courts' view, as mentioned above. While this judgment was quite controversial and has received a lot of criticism, it has been explicitly invoked and discussed in four return order decisions ${ }^{109}$ and one provisional decision in which an investigation by the Child Protection Services was ordered. ${ }^{110}$ In all these decisions the Dutch courts held that the recourse to the Neulinger judgment could not succeed, because in that case the factual circumstances were so exceptional that it is incomparable to the circumstances in the cases they are deciding upon. It is interesting to note here that one of these

\footnotetext{
${ }^{105}$ See the Report of the third Special Commission meeting to review the operation of the Hague Convention on the Civil Aspects of International Child Abduction (17-21 March 1997) https://assets.hcch.net/upload/abduc97e.pdf accessed on 22 October 2017, paras $58-60$.

${ }^{106}$ Art 11(4) Brussels IIa.

${ }^{107}$ District Court of The Hague 9 October 2014, NL:RBDHA:2014:12375; District Court of The Hague 23 April 2014, NL:RBDHA:2014:7120; District Court of Zutphen 6 March 2012, NL:RBZUT:2012:BV9527.

${ }^{108}$ Even though the considerations in this case were similar to those in Maumousseau, Neulinger is the better known case and at the time of the research had had a wider impact in Dutch case law.

${ }^{109}$ District Court of The Hague 26 January 2015, NL:RBDHA:2015:751; District Court of The Hague 24 February 2011, NL:RBSGR:2011:BP7641; District Court of Amsterdam 14 December 2010, NL:RBAMS:2010:BO9386; District Court of Utrecht 10 December 2010, NL:RBUTR:2010:BP1552.

${ }^{110}$ District Court of Breda 31 January 2011, NL:RBBRE:2011:BQ3540.
} 
judgments ${ }^{111}$ was given after the judgment in $X v$ Latvia,${ }^{112}$ in which the European Court of Human Rights nuanced the finding in Neulinger. However, the Dutch court did not refer to Xv Latvia. We do not think that the outcome of the judgment would have been different. However, it remains to be seen in later case law whether it has gained the level of recognition that the Neulinger judgment has had possibly due to all the debate the latter ignited.

A third view held by some courts is that the child must not necessarily return to or stay in the country where his or her interests are best served. According to four decisions, the argument that the child's interests would be less well served in the country of return compared to the Netherlands - even if true - is insufficient to justify the use of the exception in Article 13(1)(b) Hague Convention ${ }^{113}$ or to require the application of Article 8 ECHR. ${ }^{114}$ This view respects the ECtHR's $X v$ Latvia judgment (even though the courts do not explicitly refer to this judgment - in part because they predate the judgment) and should be commended. It respects the balance between the obligation of a speedy return based on a summary assessment and respect for the best interests of the child within this context.

More generally, the body of ECtHR case law on the child's best interests in international child abductions is taken into account by the Dutch courts. In two cases the courts explicitly stated that the best interests of the child would be included in their assessment, because the rulings of the ECtHR require this. ${ }^{115}$ This leads us to the final common view to the best interests of the child. When parties invoke Article 8 ECHR and/or Article 3 CRC, the Dutch courts emphasize that the Hague Convention aims to serve the child's best interests as protected by both human rights provisions and thus that these two provisions are "incorporated" in the Hague Convention. ${ }^{116}$ According to the Dutch courts the starting point of the Hague Convention but also the CRC and Article 8 ECHR is that international child abduction is against the child's best interests and that, as such, a return order on the basis of the

\footnotetext{
${ }^{111}$ District Court of The Hague 26 January 2015, NL:RBDHA:2015:751.

${ }^{112} X$ v Latvia, App no 27853/09 (Grand Chamber) 26 November 2013.

${ }^{113}$ Court of Appeal The Hague 10 November 2010, NL:GHSGR:2010:BP7889; Court of Appeal The Hague 28 April 2010, NL:GHSGR:2010:BM5202; District Court of The Hague 27 August 2014, NL:RBDHA:2014:10658. See also Ruitenberg (supra n 38), 323 and 332-33.

${ }^{114}$ District Court of The Hague 1 November 2012, NL:RBSGR:2012:BY3832.

${ }^{115}$ Court of Appeal The Hague 15 October 2014, NL:GHDHA:2014:3722; Court of Appeal The Hague 18 January 2012, NL:GHSGR:2012:BV5608.

${ }^{116}$ Court of Appeal The Hague 15 October 2014, NL:GHDHA:2014:3722; District Court of Groningen 26 January 2012, NL:RBGRO:2012:BV6069; District Court of The Hague 23 April 2009, NL:RBSGR:2009:BL8002; District Court of Leeuwarden 28 July 2011, NL: RBLEE:2011:BR4907; District Court of The Hague 22 August 2012, NL:RBSGR:2012: BX6631; District Court of The Hague 1 November 2012, NL:RBSGR:2012:BY3832.
} 
Hague Convention is not contrary to the child's best interests. ${ }^{117}$ Therefore, in four decisions the Dutch courts see no reason to separately assess the best interests of the abducted child in regards to Article 8 ECHR and/or Article 3 CRC outside of the framework of the Hague Convention provisions. ${ }^{118}$ Similarly, in two other cases, the courts did not separately delve into an investigation of the child's best interests, because the courts found that this did not fit in the assessment framework of the Hague procedures. ${ }^{119}$ This approach is also in line with $X v$ Latvia, the latest Grand Chamber judgment. The courts again show how it is possible to find the delicate balance between quick summary proceedings and respect for the child's best interests in that context.

One case, in which the Dutch court explicitly discusses the principle of the child's best interests and the return is ordered, stands alone. ${ }^{120}$ In this case more than a year had passed between the abduction and the institution of return proceedings. Under the Hague Child Abduction Convention the court can then take into account the fact that the child was integrated in his new surroundings, which was the case here. ${ }^{121}$ However, due to the potential prison sentence of six years that the father (the abducting parent) was facing for domestic violence, the risk existed that the child would remain in the Netherlands without the daily care of either of his parents. In light of those facts, the court held that the best interests of the child continue to be guiding in decisions about return orders. It therefore ordered the return despite the integration of the child, considering it to be in the child's best interest to reside with at least one of his parents. This case is interesting as it shows the place of the child's best interests in the application of the Convention, outside the grounds for refusal. Where the return proceedings are initiated more than a year after the abduction and it is demonstrated that the child is settled in his or her new environment, the court is not obliged to order return, in such cases courts are well-advised - if not, required - to consider the best interests of the child before nonetheless ordering the return of the child.

\footnotetext{
$\overline{{ }^{117} \text { Court of Appeal The Hague } 15 \text { October 2014, NL:GHDHA:2014:3722; District Court of }}$ Groningen 26 January 2012, NL:RBGRO:2012:BV6069; District Court of The Hague 23 April 2009, NL:RBSGR:2009:BL8002.

${ }^{11}$ Court of Appeal The Hague 15 October 2014, NL:GHDHA:2014:3722; District Court of The Hague 3 January 2013, NL:RBDHA:2013:BY8769; District Court of The Hague 27 August 2014, NL:RBDHA:2014:10658; District Court of Groningen 26 January 2012, NL:RBGRO:2012:BV6069.

${ }^{119}$ District Court of The Hague 9 October 2014, NL:RBDHA:2014:12375; District Court of The Hague 19 December 2014, NL:RBDHA:2014:16690.

${ }^{120}$ Court of Appeal's-Hertogenbosch 15 November 2006, NL:GHSHE:2006:AZ6543.

${ }^{121}$ Hague Child Abduction Convention Art 12(2).
} 


\section{F. England and Wales}

The analysis below contains the 36 judgments by the Courts in England and Wales in which the best interests of the child were explicitly discussed in the reasoning of the judge. Four of these judgments were delivered by the UK Supreme Court. ${ }^{122}$

\section{Non-return orders}

In 43 decisions out of 179 the English judges did not order the return of the abducted children, in Hague Convention cases due to the application of Article 12,13 or 20 and in non-Hague Convention cases based on the paramount interests of the child. In 17 of these 43 decisions, the judges explicitly discussed the best interests of the child.

One of the earliest of these 17 cases is a very important judgment of the House of Lords. In the 2007 case, In re M and another (Children), Baroness Hale begins her judgment with a discussion of the Hague Convention. ${ }^{123}$ According to her, this Convention is "designed to protect the interests of children by securing their prompt return", but also "recognizes some limited and precise circumstances when it will not be in their interests to do so". ${ }^{124}$ This general policy aim of prompt return together with the other policy considerations, such as comity between the Signatory States, mutual respect for each other's judicial systems and the prevention of international child abduction, "may be weighed against the interests of the child in the individual case". ${ }^{125}$ The amount of discretion judges have in the balancing acts will vary enormously depending on how appropriate it is in the case to "investigate those welfare considerations". ${ }^{126}$ This judgment grants English judges ample space to exercise their discretion with regard to the best interests of the child where the Hague Convention provides space for discretion, in this case the discretion contained in the Article 12(2) exception. This discretion places both the Hague Convention policy considerations and the individual abducted child's best interests in the balancing scale. In this case the non-return order was based on the children being settled due to the long passage of time. ${ }^{127}$ According to Baroness Hale, the policy considerations of the Hague Convention should therefore carry little weight as "these children should not be made to suffer for the sake of general deterrence of the evil of child abduction worldwide". ${ }^{128}$ Here the best interests of the individual abducted children were considered to tip the scales towards non-return. Article 8 ECHR also

\footnotetext{
${ }^{122}$ Including judgments from its predecessor, the House of Lords.

${ }^{123}$ In re $M(F C)$ and another (FC) (Children) (FC) [2007] UKHL 55.

${ }^{124}$ Ibid [12].

${ }^{125}$ Ibid [42].

${ }^{126}$ Ibid [44].

${ }^{127}$ Art 12(2) Hague Convention.

${ }^{128}$ In re $M(F C)$ and another (FC) (Children) (FC) [2007] UKHL 55, [54].
} 
made an appearance in the decision within the framework of Article 20 Hague Convention. While the right to respect for family life for the left-behind parent was recognized, a return order was considered to be a "graver interference" with the rights of the children than failing to do so would be for the rights of the left-behind parent. ${ }^{129}$

Five later cases follow the House of Lords' judgment in stressing the balancing exercise that occurs between the policy considerations of the Hague Convention and the best interests of the abducted children. ${ }^{130}$ Even though these judgments followed the Neulinger judgment, the English courts could rely on the House of Lords' interpretation, which perhaps assisted them in engaging with the best interests of the child without feeling disorientated by the ECtHR's views. In $D v O$, for example, the court of appeals emphasizes that while the Convention embodies the assumption that the child's best interests are met by a prompt return order, In re $M$ and another (Children) clarifies that "the individual circumstances of the particular child are what matter" and that these circumstances must be "examined and weighed in the balance". ${ }^{131}$ Similarly in $C B v C B$ and $R e M$ the courts reflect that they are entitled to, ${ }^{132}$ or even "must", ${ }^{133}$ consider both the Hague Convention policies and purposes and the wider considerations of the child's welfare and interests. Even though in both cases the ground for not ordering the return of the children was the child(ren)'s objection, ${ }^{134}$ the courts still weigh both aspects in contemplating the return. In the two other cases, Kinderis v Kineriene and $L S v$ $A S$, the courts also stress that they have to take account of the policy objectives of the Hague Convention and the children's best interests, but that neither are of "overriding importance". ${ }^{135}$ No principle of policy, such as the prompt return, should be given greater weight than any other policy consideration or the interests of abducted children. ${ }^{136}$ Thus the English courts manage to balance the obligations under the Hague Child Abduction Convention with those under the CRC to consider the child's best interests. Possibly the common law legal system allows judges to use their discretion flexibly in this difficult balancing exercise.

Of course, while the English courts are convinced of the necessity to include the child's best interests in the balancing act, they also recognize the value of the Hague Convention in light of the best interests. For example, in $K v B$ and $\operatorname{Re} S(A$

\footnotetext{
${ }^{129}$ Ibid [56].

${ }^{130} C B$ v CB [2013] EWHC 2092 (Fam); Dv O [2011] EWCA Civ 128; Kinderis v Kineriene (No 2) [2014] EWHC 693 (Fam); LS v AS [2014] EWHC 1626 (Fam); Re M (Republic of Ireland) (Child's Objections) (joinder of Children as Parties to Appeal) [2015] EWCA Civ 26.

${ }^{131} D$ v $O$ [2011] EWCA Civ 128.

${ }^{132} \operatorname{Re} M$ (Republic of Ireland) (Child's Objections) (joinder of Children as Parties to Appeal) [2015] EWCA Civ 26.

${ }^{133} C B$ v $C B$ [2013] EWHC 2092 (Fam).

${ }^{134}$ Art 13(2) Hague Child Abduction Convention.

${ }^{135}$ Kinderis v Kineriene (No 2) [2014] EWHC 693 (Fam).

${ }^{136} L S v A S$ [2014] EWHC 1626 (Fam).
} 
Child) the courts recognize that in normal circumstances it is in the best interests of the abducted children to be promptly returned and that only in exceptional circumstances should return be refused. ${ }^{137}$

In 6 of the 17 cases the concept of the best interests of the child was not discussed in abstract terms, but was explicitly mentioned in relation to factual issues. ${ }^{138}$ In all of these cases the courts held that a return order would not be in the children's interests. For example, in $F Q \vee M Q, E Q, D Q$ the non-return was based on the exception of Article 12(2) Hague Convention, namely that the children were considered to be settled in England, amongst other things at school and in their neighbourhood. Within the discretion offered to the court under Article 12(2), the court considered the children's best interests and found that a return order would not be in their interests because their future care and residence arrangements were uncertain and in dispute. ${ }^{139}$ The uncertainty and dispute referred to by the court was based on the allegations of severe domestic violence in combination with the difficulty for the mother to divorce from the father, because in their culture divorce was discouraged and thus all family members were urging their reconciliation.

In two other cases, $I B v M M$ and $W v W$, very similar factual circumstances made return contrary to the best interests of the children. ${ }^{140}$ There was domestic violence in both cases. In $I B v M M$ the father of the child's half-brother had attempted to commit homicide by stabbing the mother nine times in the presence of the half-brother. In $W v W$ the two elder children recounted domestic abuse. The half-brother in $I B \vee M M$ was not subject to the return proceedings and thus could remain in England far away from all the traumatic experiences and the return order for the two elder children in $W v W$ was rejected on the ground of their objections. The question thus remained whether the two remaining children in these cases had to return. A shared core argument for the courts to reject the return order was the grave risk of harm that would be caused to these two children if they were to be split from their siblings. The courts found that, because the "importance of the sibling relationship is well known", ${ }^{141}$ in both cases the life-long and significant sibling relationship would make it intolerable to separate the children from their siblings. These judgments show how the concept of the best interests of the child can be used to give content to the grave risk exception of the Hague Child

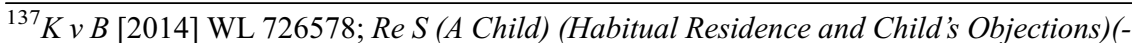
Brazil) [2015] EWCA Civ 2.

${ }^{138} A F v M B-F$ [2008] EWHC 272 (Fam); $B-G v B-G$ [2008] EWHC 688 (Fam); $D v S$ [2008] EWHC 363 (Fam); FQ v MQ, EQ, DQ (Acting through their Guardian Mrs Julian) [2013] EWHC 4149 (Fam); IB $v M M$ [2015] EWHC 1502 (Fam); $W v W$ [2010] EWHC 332 (Fam).

${ }^{139} F Q \vee M Q, E Q, D Q$ (Acting through their Guardian Mrs Julian) [2013] EWHC 4149 (Fam).

${ }^{140} I B v M M[2015]$ EWHC 1502 (Fam); $W v W$ [2010] EWHC 332 (Fam).

${ }^{141} I B \cup M M$ [2015] EWHC 1502 (Fam). 
Abduction Convention. A scenario that is clearly not in the interests of the child, as is "well known", eg from sociological research, can help judges to identify potential grave risks.

In one of the 17 cases in which return was rejected and the concept of the child's best interests was explicitly mentioned, it was brought in connection to Article 8 ECHR. In $D T v L B T$ various issues, including domestic violence (emotional, physical and sexual abuse towards the abducting parent) and one of the children's major behavioural problems, led the court to find that a return would not serve the interests of the children as the grave risk exception was found to apply. ${ }^{142}$ Because the parties had made submissions about the Grand Chamber judgment of Neulinger which had only been decided a few months earlier, the court discussed the relevance of the decision and Article 8 ECHR. The court noted that Neulinger did not "bring about a sea of change" in how international child abduction cases are dealt with. Instead it is a reminder that the ECHR is also of importance in these cases. ${ }^{143}$ In the case at hand, the court found that raising Article 8 ECHR emphasized the recognition that English judges already give "to the position of primary carers who have been subjected to domestic abuse". Therefore the right to family life of the abusive parent must be seen in light of his or her behaviour. ${ }^{144}$ This case, and the fact that it followed so soon after Neulinger greatly assisted English courts in keeping the correct perspective on the role that the best interests of the child can and should play in child abduction cases. The English courts did not have to wait for the $X v$ Latvia case to get the balance right.

The final two cases in which the return was refused concerned Non-Hague Convention cases. One of these two is the most important non-Hague Convention judgment in England and Wales: ${ }^{145}$ the House of Lords judgment In Re $J$ in 2005. ${ }^{146}$ The case concerned an abduction from Saudi Arabia and the issue brought before the House of Lords was whether and how it is relevant that the laws and procedures in the country of return, in this case Sharia law, are very different from the English laws and procedures. ${ }^{147}$ Baroness Hale in her leading judgment, with unanimous agreement of the other judges, explains that in nonHague Convention cases it had been held that the welfare of the individual child is leading in the decision whether or not to order the return. If return is in the best interests of the individual child, it may be ordered. Other - policy - considerations which may play a role in Hague Convention cases are irrelevant in

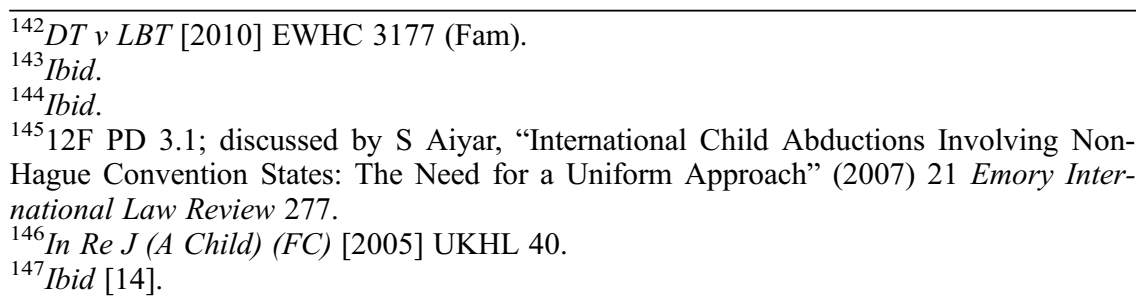


non-Convention cases. ${ }^{148}$ Therefore, a summary return order should not automatically be considered as being in the best interests of children: while it may be used as a starting point, the individual circumstances of the child must be considered and weighed. ${ }^{149}$ In regards to the difference between English laws and Sharia law, the Court found it to be a relevant consideration, but the best interests of the child prevail and the English concept of "child welfare" was considered to be "quite capable of taking cultural and religious factors into account". 150

In the second case, $A R \vee A S$, the child was also abducted from Saudi Arabia and the court applied the principles as delivered in In Re $J \cdot{ }^{151}$ Instead of applying the Hague Convention to Non-Convention cases, like the Netherlands, the courts of England and Wales should consider whether or not the return order should be granted by having the welfare of the children as a paramount consideration. In these non-Hague Convention cases, the welfare of the child, which is similar to the best interests of the child, plays a decisive role.

\section{Return orders}

The best interests of the child were discussed explicitly in 13 English decisions out of the total of 52 cases in which return was ordered. In two of these judgments (the Court of Appeal and Supreme Court judgments in the same case) the judges extensively discussed the role of the best interests of the child, also in connection to Article 8 ECHR. These two judgments will be discussed first followed by three common remarks found in the other decisions.

In Eliassen and Another $v$ Eliassen and Another ${ }^{152}$ the Court of Appeal was faced with two grounds of appeal by the abducting parent. The abducting parent averred firstly that the judge had wrongly rejected the grave risk defence and secondly that the judge had failed to apply Neulinger. Therefore, the court had to discuss in depth the ECtHR case law, the role of Article 8 and the best interests of the child. According to the court it is clear that the best interests of children is of "paramount importance" as an underlying policy of the Hague Convention, as it is in their interests to be protected from the harmful effects of abduction. ${ }^{153}$ With regards to the exception of Article 13(1)(b) Hague Convention, the court found that courts should not evaluate the "child's wider welfare" nor weigh the "ultimate best interests of the child", but that Neulinger also emphasized that the focus should be on the specific risks and the immediate best interests of the child. ${ }^{154}$ It understood Neulinger, and the later ECtHR case law, in this way

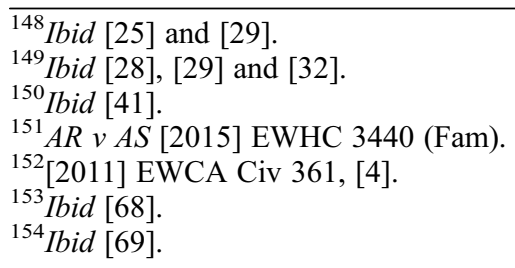


because it had to be read "in light of the endorsement by the ECtHR of the aims and objectives of the Hague Convention". ${ }^{155}$

Following the return decision of the Court of Appeal, the abducting parent appealed and argued before the UK Supreme Court that the application of the grave risk defence had not properly respected the best interests of the child as protected by Article 3(1) CRC, also in connection to the Neulinger judgment regarding Article 8 ECHR. ${ }^{156}$ The Supreme Court found that, while the best interests of the child are not explicitly considered in international child abduction proceedings, it "does not mean that they are not at the forefront of the whole exercise". ${ }^{157}$ The aim of the Hague Convention supports this. The Convention was not drafted in the interests of the parents or institutions, but for children generally and for the individual abducted child. The aim is to deter parents from abducting, but also to ensure that the abducted children's best interests are protected. The latter is done through the rebuttable assumption in the Hague Convention that the prompt return of the child is in his or her best interests. The exceptions in Articles 12 and 13 apply when this general assumption does not fit the individual child's best interests. The Supreme Court thus concludes that the Hague Convention, as well as the Brussels IIa Regulation, does have the best interests of the child as "a primary consideration" and that while it could potentially be further developed to reflect this, the current procedure already complies with the CRC and the ECHR. ${ }^{158}$ The Supreme Court thus finds that if the Hague Convention is properly applied, the best interests of the child should have formed a primary consideration and thus a violation of Article 8 ECHR will be extremely unlikely. According to the Supreme Court, while the ECtHR has decided in Neulinger that an examination of the child's best interests is required, courts need not conduct a total welfare examination. The current approach in England and Wales is therefore sufficient. With this conclusion, the Supreme Court again anticipates what the ECtHR will find, this time in $X v$ Latvia.

Finally, the UK Supreme Court repeats and agrees with the ECtHR's twolimbed understanding of the children's best interests in international abduction cases: (1) children should be reunited with their parents as soon as possible and (2) children should be brought up in a "sound environment" without risk of harm.

In the other 10 Hague Convention return cases three common remarks are made in regards to the best interests of the child. A few of these were also clearly influenced by the Supreme Court decision discussed above.

The first common remark concerns Article 13(1)(b) Hague Convention. In 2005 it was already recognized as being included to protect the interests of children generally. ${ }^{159}$ Following the Supreme Court judgment, in 2013 the court in

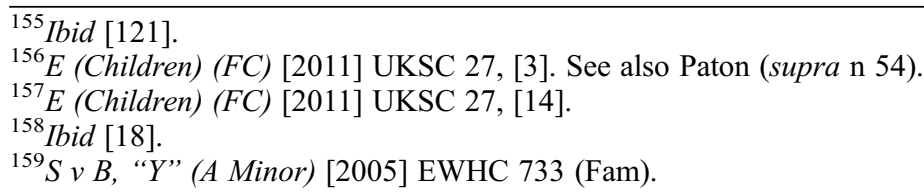


$C v D$ also emphasized that the interests of the individual child are taken into account by this exception and that aside from the provisions in Article 12 and 13 , there is no room for the best interests of the child to "trump" a return order. ${ }^{160}$ Allowing such a trump would nullify the aims and policies behind the Hague Convention. In Re B the same sentiment is expressed, the welfare of the child is not paramount but it is a factor to be taken into account. ${ }^{161}$

The second common remark concerns the aim and policy considerations of the Hague Convention. In both $C v S$ and $\operatorname{Re} G$ the courts stress that the best interests of children as a primary consideration is an inherent assumption in the Hague Convention and that it is generally in the best interests of children not to be abducted, to be returned to their country of habitual residence as soon as possible, and for the Convention to deter abduction in the first place. ${ }^{162}$

Lastly, in five cases courts found that a return was in the best interests of the child because the courts of the country of habitual residence would be able to best serve the best interests of the child in making the long-term welfare decisions. ${ }^{163}$ Generally, this is considered to be in the best interests as it is in accordance with the intention of the Hague Convention. ${ }^{164}$ But more specifically, in $F v M, B$ this was considered to be the case because the court of habitual residence had access to many previous reports and thus offered more judicial continuity, ${ }^{165}$ and in $F v M$, $N$ the court of habitual residence was considered to be able to make the decisions as speedily and effectively as possible. ${ }^{166}$ It emerges from these common remarks that the English courts often do not see a dichotomy between the best interests of the child in the case before them and the obligation to return abducted children, but rather view them in line with each other.

The final two return cases in which the best interests of the child were explicitly mentioned were not typical Hague Convention return orders. The first concerned a Non-Hague Convention return order. In $A v B$, Re $S$ from 2015, in which a child was abducted from Abu Dhabi, the court bases its decision on the legal principles as derived from In Re $J$, the House of Lords decision discussed above. ${ }^{167}$ Therefore, it considers that the return of the child must occur if it is in the best interests of the child; other considerations may play a role but are

\footnotetext{
${ }^{160} C$ v D (Abduction, Grave Risk of Harm) [2013] EWHC 2989 (Fam).

${ }^{161}$ Re B (A Child) (1980 Hague Convention Proceedings) [2014] EWCA Civ 375.

${ }^{162}$ Cv S (Child Abduction, Hague Convention, Article 13) [2014] EWHC 3799 (Fam); Re G (A Minor) [2014] EWHC 3541 (Fam).

${ }^{163} D v S$ [2008] EWHC 363 (Fam); Fv M, B (by his Litigation Friend) [2015] EWHC 3300 (Fam); Fv M, N (by her Children's Guardian) [2008] EWHC 1525 (Fam); In the Matter of $H, R$ and E (Children) [2013] EWHC 3857 (Fam); JPC v SLW, SMW [2007] EWHC 1349 (Fam).

${ }^{164} J P C$ v SLW, SMW [2007] EWHC 1349 (Fam).

${ }^{165} F$ v M, B (by his Litigation Friend) [2015] EWHC 3300 (Fam).

${ }^{166} F v M, N$ (by her Children's Guardian) [2008] EWHC 1525 (Fam).

${ }^{167}$ A v B, Re $S$ (Wardship, Summary return, non-Convention country) [2015] EWHC 176 (Fam).
} 
not paramount. The second case, $B v D$, concerned a return procedure for two children abducted from England to Portugal under the inherent jurisdiction of the High Court. ${ }^{168}$ Although the mother could have instituted Hague Convention return proceedings in Portugal, the court found that the mother could also approach the domestic courts. It then ordered the return of the children, finding that the return would be in their best interests. Specifically, because "the issues between their parents should be litigated in the country of their true habitual residence". ${ }^{169}$

\section{Overriding return procedure}

One case concerned proceedings under the second chance procedure of Brussels IIa. ${ }^{170}$ The High Court in $D v N \& D$ found that it also had to consider whether a return order is in the child's best interests. ${ }^{171}$ The court considered it in the child's interest to return if the mother would return with her and be present at the general welfare hearing. The second chance ruling trumps the non-return order given by the court of the place to which the child was abducted. It is something between the return order and a custody decision: it is not part of the return order as provided by the Hague Child Abduction Convention but it extends the return phase of the proceedings. At the same time, they can be joined with custody proceedings (depending on the national procedural rules ${ }^{172}$ ). In this light it makes sense that the best interests of the child must be examined in overriding return proceedings.

\section{No wrongful removal or retention}

In 12 cases the courts found that there was no wrongful removal or retention, thus did not have to order the return of the children. In five of these cases the courts also reflected explicitly on the best interests of the child. For example, in $A v S$ the court found that it would not be in the interests of the child to return, in part because a decision on the long-term welfare of the child had to be taken as soon as possible and that was more likely to occur in England than in the country of return. ${ }^{173}$ The House of Lords in In re D (a child) found that there had not been a wrongful removal from Romania and thus the child did not need to be returned. ${ }^{174}$ In addition, Lord Hope of Craighead emphasized that return would not be in the child's best interests due to the excessive delays in the case (four years of

\footnotetext{
${ }_{168}^{B} v D[2008]$ EWHC 1246 (Fam).

${ }^{169}$ Ibid.

${ }^{170}$ Art 11(6)-(8) Brussels IIa.

${ }^{171} D$ v $N \&$ \& (By her Guardian ad Litem) [2011] EWHC 471 (Fam).

${ }^{172}$ In the European Commission's Proposal for the Brussels IIa Recast (supra n 36), the second chance proceeding is always embedded in the custody proceedings: see Art 26(4).

${ }^{173} A \cup S[2015]$ EWFC 16.

${ }^{174}$ In re D (a child) (Abduction: Rights of Custody) [2006] UKHL 51.
} 
proceedings). In both $D L v E L$ and $F B v I B$ the courts explicitly stated that even if the Hague Convention were to apply, it would still not be in the best interests of the child to return. ${ }^{175}$ Finally, in $A v T$ the court, while finding there to be consent for the removal of the child, it still considered the best interests of the child in its discretion. ${ }^{176}$ In doing so, the court referred to the principles laid down in In re M and another (Children), that the best interests of the child are not the paramount factor but must instead be weighed together with the other policy considerations. It is interesting to note that the English courts still discuss the child's best interests even when there is no need to do so because the case can be decided on the technical point of a lack of wrongful removal or retention. This signals that the English courts take the interests of the child seriously, or they feel the need to justify their decisions on the basis of children's best interests.

\section{G. Evaluation of the interpretation of "best interests"}

Following this comprehensive analysis of the case law, it is time to evaluate and compare the explicit use of the child's best interests in both jurisdictions and in light of the case law of the European Court of Human Rights.

Our first observation is that there is a difference in the ways in which courts in England and Wales and courts in the Netherlands employ the principle of the best interests of the child in their judgments. English courts more often explicitly refer to the best interests of the child. Moreover, they also give more content to the principle, rather than inserting a formulaic reference to it at the end of the judgment as Dutch courts tend to do. The English courts consider the best interests of the child in relation to particular facts. This, we think, is due to the different approach of common law, where facts and law are more difficult to distinguish. Courts are therefore less likely to apply legal principles in an abstract manner. They explicitly link the applicable principles to the facts at hand, ie the situation of the child before them.

The Dutch approach does not mean that the Dutch courts are not concerned with children's interests. They do attempt to adhere to their international law obligations, even when these sometimes appear inconsistent with each other. There is a marked difference between judgments ordering return and those refusing return. Where the return is refused, courts refer to the family ties of the child, the role of the primary caretaker, the contact with the other parent, the emotional connection with the parents, the languages the child speaks and ability to communicate with both parents. These factors linked to the best interests of the child are used to justify the non-return, ie the use of the grounds for refusal.

Where the Dutch courts order the return, they seek to align the Hague Child Abduction Convention with the best interests of the child. They consider return as a starting point in acting in the best interests of the child. In some instances

${ }^{175} D L v E L$ [2013] EWHC 49 (Fam); FB v IB [2014] EWHC 759 (Fam).

${ }^{176} A \cup T$ [2011] EWHC 3882 (Fam). 
they explicitly state that a quick return to the situation prior to the abduction is in the best interests of the child. Such conclusion, however, seems insufficient to us when considered in the light of the ECtHR case law: it does not take account of the specific child, but of children in general, while the ECtHR has emphasized the importance of looking at the best interests of the individual child, albeit in a summary way. More often the Dutch courts consider the best interests of the child at the end of the judgment, without further reference to the specific child's situation, and come to the conclusion that their order also respects these best interests. As the courts repeatedly do so by using exactly the same text, it seems as if the best interest consideration at the end of the judgment is a type of protective measure to prevent an appeal on those grounds.

In the English case law we also find the point of departure that the Hague Convention is designed to protect the interests of the child. This is probably thanks to the timely and concrete guidance that the House of Lords gave already in 2007 in In re M and another (Children). The House of Lords clarified that the policy objectives of the Convention cannot prejudice the best interests of individual children. We consider this a pivotal judgment at a crucial time, which helped English courts to find the right balance. Another important judgment was $D T v L B T$ where the High Court explicitly referred to Neulinger and gave guidance as to its further interpretation in child abduction cases in domestic courts. The English courts' method of considering the child's best interests in light of the facts and context of the case is similar both for return as for non-return orders.

Looking at the concrete elements that the courts in England and Wales and in the Netherlands take into account when they assess the child's interests, the difference is minimal. Sometimes more explicitly than other times, the courts consider the safety of children and their family ties. Under the first consideration, they take account of the child's age and aim to protect him or her from domestic violence. Under the second consideration, they take care to ensure that the child should not be cut off from family members (including parents and siblings) and that the child must be able to communicate with the family members with which he or she lives and with those in another country (this raises issues of language and technology). Courts in both countries seem to realize the importance of speedy proceedings.

Perhaps the most interesting question which can be answered by this case law analysis is how the judgments of the European Court of Human Rights have impacted the use of the child's best interests in national courts' decisions. It is undisputed that the national courts could not overlook the Neulinger judgment. In England and Wales, as mentioned above, the High Court in $D T v L B T$ provided guidance on how to balance the child's best interests and the Hague Convention following the crucial House of Lord's judgment. In addition the Supreme Court in $E$ (Children) further emphasized the importance of this balance. In the Netherlands, the two-limb test of Maumousseau and Neulinger remain of great relevance for assessing the child's best interests in child abduction cases. However, the courts have not blindly followed the ECtHR in Neulinger. When the judgment was invoked by parties in national proceedings, the Dutch courts repeatedly 
clarified that the factual circumstances of Neulinger were exceptional and thus not comparable to the current proceedings. Finally, it is noteworthy that although $X v$ Latvia made less waves in the case law analysed, the "harmonious interpretation" proposed by the ECtHR in that judgment has found its way into national court's use of the child's best interests - in the Netherlands and England and Wales.

In the Netherlands the courts use the same test and consider the same grounds for refusal in all cases, whether or not they fall under the Hague Convention. In England, the approaches are different both in legal method and in outcome. Where children are abducted to England and Wales from non-Hague countries, the courts consider the return without regarding the rigorous mechanism of the Convention. Courts take the welfare of the child as its starting point, in line with the Children's Act.

\section{H. Conclusion}

This article has demonstrated how courts grapple with the obligations under the Hague Child Abduction Convention while attempting to respect the best interests of the child. Their task has not been facilitated by the case law of the European Court of Human Rights, which has required an assessment of the best interests of each particular child. Courts can no longer deem the interests of the child to be served by ordering a return. Through our research it becomes apparent that when the courts in the Netherlands and in England and Wales explicitly delve into the issue of the child's best interests, they take this duty seriously. However, in many decisions the interests of the child were not discussed explicitly. What this means has not been explored in this research as the aim of this paper has been to discuss how judges employ the concepts of the child's best interests in their judicial reasoning on paper, but it is an interesting observation which raises questions for further research.

Research on this matter is ongoing and we have collected and analysed case law from Belgium, France and Switzerland ${ }^{177}$ as well as South Africa. ${ }^{178}$ Currently we are expanding the case law analysis to other EU countries in a project co-funded by the European Commission (VOICE). ${ }^{179}$ Part of the research includes interviews and workshops with judges. This will allow us to engage further with judicial reasoning (explicit and implicit) in this field and to explain differences and similarities between different jurisdictions, as well as contributing to a debate on how the child's best interests should be determined and weighed.

\footnotetext{
${ }^{177}$ This research has been published by Tine Van Hof and Thalia Kruger, "Separation from the Abducting Parent and the Best Interests of the Child: A Comparative Analysis of Case Law in Belgium, France and Switzerland" (2018) 65 Netherlands International Law Review 131-153.

${ }^{178}$ Thalia Kruger is conducting this research.

${ }^{179}$ Project partners are Missing Children Europe, Child Focus, Centrum IKO, MIKK, and the Universities of Antwerp, Ghent and Genoa.
} 